\title{
THE TAXONOMICAL CHARACTERIZATION OF SOME HELVELLA AND ITS RELATIVES BY MORPHOLOGICAL AND MOLECULAR DATA FROM TURKEY
}

\author{
AKTAŞ, S. ${ }^{*}$ - KARASELEK, M. A. \\ Department of Biology, Faculty of Science, Selçuk University, Konya, Turkey \\ *Corresponding author \\ e-mail: sinaktas@yahoo.com; phone:+90-332-223-1867; fax: +90-332-241-2499 \\ (Received 28 ${ }^{\text {th }}$ Feb 2019; accepted $3^{\text {rd }}$ May 2019)
}

\begin{abstract}
Herein, 15 fungi species belonging to different genera of Pezizales were studied morphologically and molecularly. During the morphological analyses performed by means of Primer 7 software, 28 characters were used, mainly including the stalk, cap, asci, and spores, to assess the taxonomical relationships of the fungi species. The data matrix and nMDS plot approaches based on the morphological data were highly functional in the determination of the taxonomical relationship of very closely related fungi taxa, particularly at the genus level. Moreover, the data from the ISSR locus analyses significantly supported the current morphological relationships on a wide scale. Contrary to the morphological data expressing taxonomical relationships related to morels or early morels, a minor exceptional condition was determined inferring to the relatively higher genetic similarity among Verpa and Gyromitra in the dendrogram connected with the ISSR analyses.
\end{abstract}

Keywords: fungi, DNA, genetic relationships, ISSR, numerical analyses

\section{Introduction}

Helvella $\mathrm{L}$. is a widespread and interesting genus of large apothecial ascomycet (Pezizomycete: Pezizales J. Schröt.) that are found in terrestrial biomes of the Northern and Southern Hemispheres. The genus contains many of the larger and charismatic species of the order Pezizales and comprises a range of elaborate apothecia, from cupulate to saddle-shaped, and convex to campanulate, including species with folded and lobed caps seated on a simple, ribbed, or furrowed stipe (Skrede et al., 2017). Compared to other close relatives, Helvella is a relatively more crowded group in terms of the number of taxa and it is represented by 21 species in Turkey (Sesli and Denchev, 2014).

Morchella Dill. ex Pers. taxa are known as Morels, which occur in different types of forests with different mycelial dynamics, alternating between saprotrophic and symbiotic behaviors (Stefani et al., 2010). The changes in the developmental process may induce a high degree of variability in the ascocarps (Yoon et al., 1990).

Verpa $\mathrm{Sw}$. is a genus of ascomycete fungi related to the morels, resembling the latter genus; hence, they are called false or early morels. There are 5 species in the widespread genus (Kirk et al., 2008). Verpa comes from the Latin for erection or little rod. Thus, the 3 genera are now included in the family Morchellaceae Rchb. (O’Donnell et al., 1997).

Gyromitra esculenta (Pers.) Fr. is a beautiful spring time mushroom that is often encountered by morel hunters in northern and montane areas of the continent. It can be distinguished from other species of Gyromitra Fr. by its convoluted and brain-like, reddish-brown cap, and by the fact that its stem is not massive in proportion to its cap 
(Kuo, 2014). Additionally, the species display high similarity with morel taxa in terms of their ascocarp features.

Sarcoscypha coccinea (Jacq.) Sacc., commonly known as the scarlet elf cup, or the scarlet cup, is a species of fungus in the family Sarcoscyphaceae Le Gal ex Eckblad of the order Pezizales. The fungus, widely distributed in the Northern Hemisphere, has been found in Africa, Asia, Europe, North and South America, and Australia. The type species of the genus Sarcoscypha Roum., S. coccinea, has been known by many names since its first appearance in the scientific literature in 1772. The species was originally named Helvella coccinea by the Italian naturalist Giovanni Antonio Scopoli in 1772 (Scopoli, 1772). Other early names include Peziza coccinea (Jacquin, 1774) and Peziza dichroa (Holmskjold, 1799). Although some authors in older literature have applied the generic name Plectania to the taxon, following Fuckel's 1870 name change (e.g., Seaver, 1928; Kanouse, 1948; Nannfeldt, 1949; Le Gal, 1953), that name is now used for a fungus with brownish-black fruit bodies (Korf and Harrington, 1990). S. coccinea was given its current name by Lambotte in 1889 .

In recent years, developments in molecular biology and genetic have made inevitable the emergence of new techniques in the systematic field, and these developments have also been effective in fungal systematics. Previous classifications of the fungi could be checked via molecular studies to determine whether it is natural or not. The marker system, called inter-simple sequence repeats (ISSRs), is also a polymerase chain reaction (PCR)-based technique (Wolfe, 1998) that has been successfully applied for the genetic analyses of plants (Fang et al., 1997; Prevost et al., 1999; Song et al., 2006; Uysal et al., 2012 a, b; Bozkurt et al., 2013) and fungal classification (Tang et al., 2005). In particular, ISSR markers can be highly variable within a species and have an advantage over others in utilizing longer primers that allow more stringent annealing temperatures (Camacho and Liston., 2001; Tsumura et al., 1996; Nazrul and Bian, 2010). Recently, the development of molecular systematics, thanks to ISSR and similar molecular markers, has made it possible to identify specimens of closely related species and, to some extent, it has been applied to taxonomic studies of Helvella (Landvik et al., 1999; Nguyen et al., 2013; Landeros et al., 2015; Ariyawansa et al., 2015; Zhao et al., 2017). In previous studies were also reported that some cryptic fungi species would be recognized by means of applying molecular markers (Nguyen et al., 2013; Balasundaram et al., 2015). Hence, ISSR has been chosen for the taxonomical characterization of some Helvella taxa from Turkey herein. Our aim was to first reveal the natural taxonomical positions of some Helvella species with their taxonomical characters and then solve the natural relationships between Helvella and its relatives.

\section{Materials and methods}

In this study, 15 Ascomycota taxa were collected from different localities in Turkey (Table 1 and Fig. 1).

\section{Morphology}

The morphological analyses of the studied fungi taxa were conducted on 15 samples from each taxa in the field from 2011-2016. A total of 28 qualitative (15) and quantitative (13) morphological characters were used (Table 2). The diagnostic traits at the species or genera level were measured, including the stalk, ascocarp, cap, spores, and asci. The qualitative and quantitative characters determined were measured and 
scored over the samples and finally turned into a data matrix. Morphometric data (Table 2) were analyzed using multivariate techniques with the PRIMER7 software package (Plymouth Marine Laboratory, Plymouth, UK; Clarke and Warwick, 1994). The Bray-Curtis similarity matrix was used to generate a 2-dimensional ordination plot applying non-metric multidimensional scaling in the PRIMER7 software (nMDS; Clarke, 1993).

Table 1. Ascomycota taxa used for ISSR and morphological analyses

\begin{tabular}{|c|c|c|}
\hline $\begin{array}{l}\text { Sample } \\
\text { number }\end{array}$ & Taxa & Locality, Collector(s) and collector's number \\
\hline HM1 & Helvella ephippium Lév. & $\begin{array}{l}\text { Adana, pine forest, } 30.10 .2011 \text {, Aktaş 1112; Isparta, pine } \\
\text { forest, 17.12.2011, Aktaş 1128; Amasya, pine forest, } \\
\text { 20.04.2012, Aktaş 1130; Amasya, pine forest, 22.04.2012, } \\
\text { Aktaş 1145; Amasya, pine forest, 23.04.2012, Aktaş 1152; } \\
\text { Amasya, pine forest, 11.06.2012, Aktaş 1154; Amasya, pine } \\
\text { forest, 12.06.2012, Aktaş 1158 }\end{array}$ \\
\hline HM2 & H. lacunosa Afzel. & $\begin{array}{l}\text { Antalya, fir forest, 26.11.2011, Aktaş 1122; Amasya, fir- } \\
\text { pine forest, 21.04.2012, Aktaş 1142; Amasya, fir-pine } \\
\text { forest, 22.04.2012, Aktaş } 1146\end{array}$ \\
\hline HM3 & H. leucomelaena (Pers.) Nannf. & $\begin{array}{c}\text { Adana, pine forest, 28.10.2011, Aktaş 1111; Antalya, pine } \\
\text { forest, 25.11.2011, Aktaş 1119; Antalya, pine forest, } \\
\text { 26.11.2011 Aktaş 1121; Isparta, pine forest, 16.12.2011, } \\
\text { Aktaş 1125; Amasya, pine forest, 20.04.2012, Aktaş 1131; } \\
\text { Amasya, pine forest, 21.04.2012, Aktaş 1141; Amasya, pine } \\
\text { forest, 22.04.2012, Aktaş 1147; Amasya, pine forest, } \\
\text { 10.06.2012, Aktaş 1153; Amasya, pine forest, 11.06.2012, } \\
\text { Aktaş 1155 }\end{array}$ \\
\hline HM4 & H. queletii Bres. & $\begin{array}{l}\text { Antalya, fir forest, 27.11.2011, Aktaş 1123; Amasya, fir- } \\
\text { pine forest, 20.04.2012, Aktaş 1132; Amasya, fir-pine } \\
\text { forest, 12.06.2012, Aktaş } 1157\end{array}$ \\
\hline HM5 & H. acetabulum (L.) Quél. & 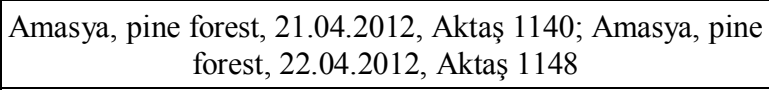 \\
\hline HM6 & H. spadicea Schaeff. & $\begin{array}{l}\text { Isparta, among poplar woods, } 16.12 .2011 \text {, Aktaş 1124; } \\
\text { Amasya, among poplar woods, } 20.04 .2012 \text {, Aktaş 1133; } \\
\text { Amasya, among poplar woods, 21.04.2012, Aktaş } 1139\end{array}$ \\
\hline HM13 & H. crispa Sowerby & Antalya; Akseki, fir-pine forest, 26.11.2011, Aktaş 1121 \\
\hline HM14 & H. solitaria P. Karst. & Samsun; Ladik, beech forest, 22.10.2016, Aktaş 2033 \\
\hline HM15 & H. leucopus Pers. & Konya; Akşehir, near stream, 15.10.2016, Aktaş 2027 \\
\hline HM7 & Peziza michelii (Boud.) Dennis & Amasya, pine forest, 23.04.2012, Aktaş 1153 \\
\hline HM8 & P. varia (Hedw.) Alb. \& Schwein. & Amasya, pine forest, 22.04.2012, Aktaş 1149 \\
\hline HM9 & Gyromitra esculenta (Pers.) Fr. & $\begin{array}{l}\text { Antalya, pine forest, 25.11.2011, Aktaş 1120; Amasya, fir- } \\
\text { pine forest, 21.04.2012, Aktaş 1138; Amasya, pine forest, } \\
\text { 20.04.2012, Aktaş 1134; Amasya, pine forest, 21.04.2012, } \\
\text { Aktaş 1143; Amasya, pine forest, 12.06.2012, Aktaş } 1156\end{array}$ \\
\hline HM10 & Verpa conica (O.F. Müll.) Sw. & Amasya, among poplar woods, 21.04.2012, Aktaş 1136 \\
\hline HM11 & Sarcoscypha coccinea (Gray) Boud. & $\begin{array}{l}\text { Isparta, pine forest, 16.12.2011, Aktaş 1126; Isparta, pine } \\
\text { forest, 17.12.2011, Aktaş 1127; Isparta, pine forest, } \\
\text { 18.12.2011, Aktaş 1129; Amasya, pine forest, 23.04.2012, } \\
\text { Aktaş } 1150\end{array}$ \\
\hline HM12 & Morchella esculenta (L.) Pers. & $\begin{array}{c}\text { Amasya, pine forest, 20.04.2012, Aktaş 1135; Amasya, pine } \\
\text { forest, } 21.04 .2012, \text { Aktaş 1137; Amasya, pine forest, } \\
\text { 22.04.2012, Aktaş } 1144\end{array}$ \\
\hline
\end{tabular}




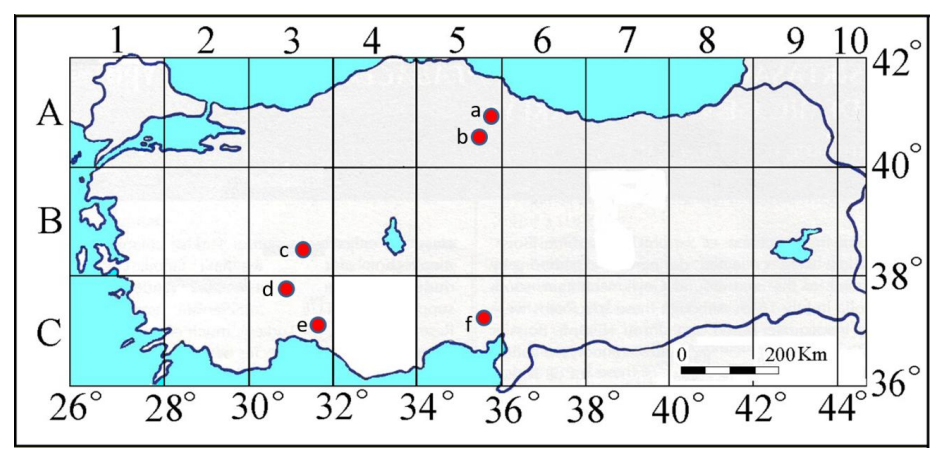

Figure 1. The location of collected samples on map (a: Samsun; $b$ : Amasya; $c$ : Konya; $d$ : Isparta; e: Antalya; $f$ : Adana)

Table 2. Characters used in numerical analysis

\begin{tabular}{|c|c|c|}
\hline \multicolumn{3}{|c|}{ Diagnostic characters of the Ascomycota species } \\
\hline Stalk & Absent $(0)$, present $(1)$ & HS1 \\
\hline Stalk & $\begin{array}{c}\text { Whitish (0), yellowish (1), brownish (2), blackish (3), absent } \\
\text { (4) }\end{array}$ & HS2 \\
\hline Stalk & Smooth (0), ribbed or veined (1), absent (2) & HS3 \\
\hline Stalk & $\begin{array}{l}\text { Narrowed at the base (0), enlarged at the base (1), same } \\
\text { anywhere (2), absent (3) }\end{array}$ & HS4 \\
\hline Stalk & $\begin{array}{l}\text { Up to } 20 \mathrm{~mm}(0), \text { between } 21-50 \mathrm{~mm}(1), 51-80 \mathrm{~mm} \mathrm{(2),} \\
\text { more than } 81 \mathrm{~mm} \mathrm{(3)}\end{array}$ & HS5 \\
\hline Stalk & $\begin{array}{c}\text { Up to } 15 \mathrm{~mm}(0) \text {, between } 16-30 \mathrm{~mm}(1), \text { more than } 31 \mathrm{~mm} \\
\text { (2) }\end{array}$ & HS6 \\
\hline Rate of stalk length/diameter & Unit & HS7 \\
\hline The type of ascocarp & Apothecium (0), other (1) & HS8 \\
\hline Ascocarp & Saddle-shaped (0), cup-shaped (1), Globose (2), conical (3) & HS9 \\
\hline Ascocarp & Smooth (0), lobed (1), curved-brain (2), alveolate (3) & HS10 \\
\hline Ascocarp (outer surface) & Cream (0), reddish-brown (1), yellowish (2), greyish (3) & HS11 \\
\hline Ascocarp (inner surface; Hymenium) & $\begin{array}{c}\begin{array}{c}\text { Greyish brown (0) brownish-black (1) yellowish (2), reddish- } \\
\text { brown (3), red (4), light brown (5) }\end{array} \\
\end{array}$ & HS12 \\
\hline Ascocarp (inner surface; Hymenium) & Glabrous (0), hairy (1) & HS13 \\
\hline Cap & Up to $25 \mathrm{~mm}(0), 26-60 \mathrm{~mm}(1)$, more than $61 \mathrm{~mm} \mathrm{(2)}$ & HS14 \\
\hline Cap & Up to $25 \mathrm{~mm}(0), 26-60 \mathrm{~mm} \mathrm{(1),} \mathrm{more} \mathrm{than} 61 \mathrm{~mm} \mathrm{(2)}$ & HS15 \\
\hline Rate of cap length/diameter & Unit & HS16 \\
\hline Cap & Convex $(0)$, concave $(1)$, semi-convex (2) & HS17 \\
\hline Spores & Ellipsoidal (0), elliptic (1), weakly-elliptic (2) & HS18 \\
\hline Spores (oil drop number) & Only one (0), two (1), more (2) & HS19 \\
\hline Spores (oil drop position) & Inside of spores (0), outside of spores (1) & HS20 \\
\hline Spores & Between 16 and $21 \mu \mathrm{m}(0), \underset{(2)}{22-27 \mu \mathrm{m}(1), \text { more than } 27 \mu \mathrm{m}}$ & HS21 \\
\hline Spores & Between 8 and $10 \mu \mathrm{m}(0), 11-13 \mu \mathrm{m}(1), 14-16 \mu \mathrm{m}(2)$ & HS22 \\
\hline Rate of spore length/diameter & Unit & HS23 \\
\hline Spores (surfacial) & Smooth $(0)$, verrucose (1) & HS24 \\
\hline Asci & $\begin{array}{c}\text { Between } 225 \text { and } 300 \mu \mathrm{m}(0), 301-375 \mu \mathrm{m}(1) \text {, more than } \\
376 \mu \mathrm{m}(2)\end{array}$ & HS25 \\
\hline Asci & Between 14 and $18 \mu \mathrm{m}(0)$, more than $18 \mu \mathrm{m}(1)$ & HS26 \\
\hline Rate of asci length/width & Unit & HS27 \\
\hline Asci (number of spores) & Number & HS28 \\
\hline
\end{tabular}




\section{DNA extraction}

Total genomic DNA was extracted following the $2 \mathrm{xCTAB}$ method of Doyle and Doyle (1987) as was modified by Soltis et al. (1991) and Cullings (1992) from silica gel-dried leaves collected in the field.

\section{ISSR-PCR}

Our modified ISSR-PCR analyses were basically performed according to the method of Zietkiewicz et al. (1994). During the PCR-optimization reactions, some modifications were quantitatively carried out, particularly for the $\mathrm{Mg}$ and primer amounts, as well as the Tm selection. The designed ISSR primers by British Colombia University were chosen for the PCR-amplifications. Amplification products were separated by electrophoresis in $1.2 \%$ agarose gel run in a TAE buffer at $100 \mathrm{~V}$. The fragment size was estimated using a $20,000-75$ bp molecular size DNA ladder (Thermoscientific, SM1331).

\section{Data analysis}

The ISSR profiles were scored as present (1) or absent (0). Only reproducible bands were scored as monomorphic or polymorphic. The dendrogram was created using NTSYS-pc version 2.1 (Rohlf, 1998).

\section{Results}

\section{Molecular results}

A total of 15 taxa were tested with 20 ISSR primers and only 10 of them provided reproducible and analyzable amplification products for all taxa and a total of 477 bands ranging from 80-2500 bp were obtained to put the relativeness of the fungi species (Fig. 2). All of the ISSR primers showed 100\% polymorphism for Ascomycota taxa (Table 3).

Table 3. Number and percentage of polymorphic ISSR markers

\begin{tabular}{c|c|c|c|c}
\hline Primers & Primer sequences (5'-3') & $\begin{array}{c}\text { Fragment size } \\
\text { (bp) }\end{array}$ & $\begin{array}{c}\text { Total number of } \\
\text { bands }\end{array}$ & $\begin{array}{c}\text { Total number of } \\
\text { polymorphic bands }\end{array}$ \\
\hline UBC827 & ACA CAC ACA CAC ACA CG & $1500-100$ & 47 & 47 \\
UBC812 & GAG AGA GAG AGA GAG AA & $1400-80$ & 47 & 47 \\
UBC810 & GAG AGA GAG AGA GAG AT & $1250-80$ & 51 & 51 \\
UBC847 & CAC ACA CAC ACA CAC ARC & $1100-80$ & 35 & 35 \\
UBC857 & ACA CAC ACA CAC ACA CYG & $2000-80$ & 46 & 46 \\
UBC808 & AGA GAG AGA GAG AGA GC & $1250-80$ & 46 & 46 \\
UBC855 & ACA CAC ACA CAC ACA CYT & $2000-250$ & 45 & 45 \\
UBC834 & AGA GAG AGA GAG AGA GYT & $2500-80$ & 79 & 79 \\
UBC840 & GAG AGA GAG AGA GAG AYT & $1750-80$ & 45 & 45 \\
UBC856 & ACA CAC ACA CAC ACA CYA & $1250-80$ & 36 & 36 \\
\hline
\end{tabular}

When we look at the dendrogram that was created using the locus analysis based on the ISSR primers, all of the Helvella taxa were positioned together as only one group (Fig. 3). However, the relationships and positions of the Helvella species among 
themselves did not fit exactly with the performed previously classification on a morphology basis. In the dendrogram, the Helvella species displayed very close genetic relationships with at least $80 \%$ similarity and they were placed in the core of dendrogram. As the furthest taxa, Morchella esculenta was placed in the outermost area with $75 \%$ similarity to others. Compared to the first taxa, Sarcoscypha coccinea showed a closer similarity with the remaining taxa and its genetic relationship was more than $76 \%$. Another relatively smaller group (subclade B) consisted of 3 taxa representing 3 different genera and they showed at least $81 \%$ genetic similarity. Even if classified morphologically in different families, Gyromitra esculenta is genetically closer to Verpa conica when compared to Peziza and others analyzed herein. Naturally, Peziza michelii and $P$. varia are very similar genetically and the distance between them is less than $15 \%$.

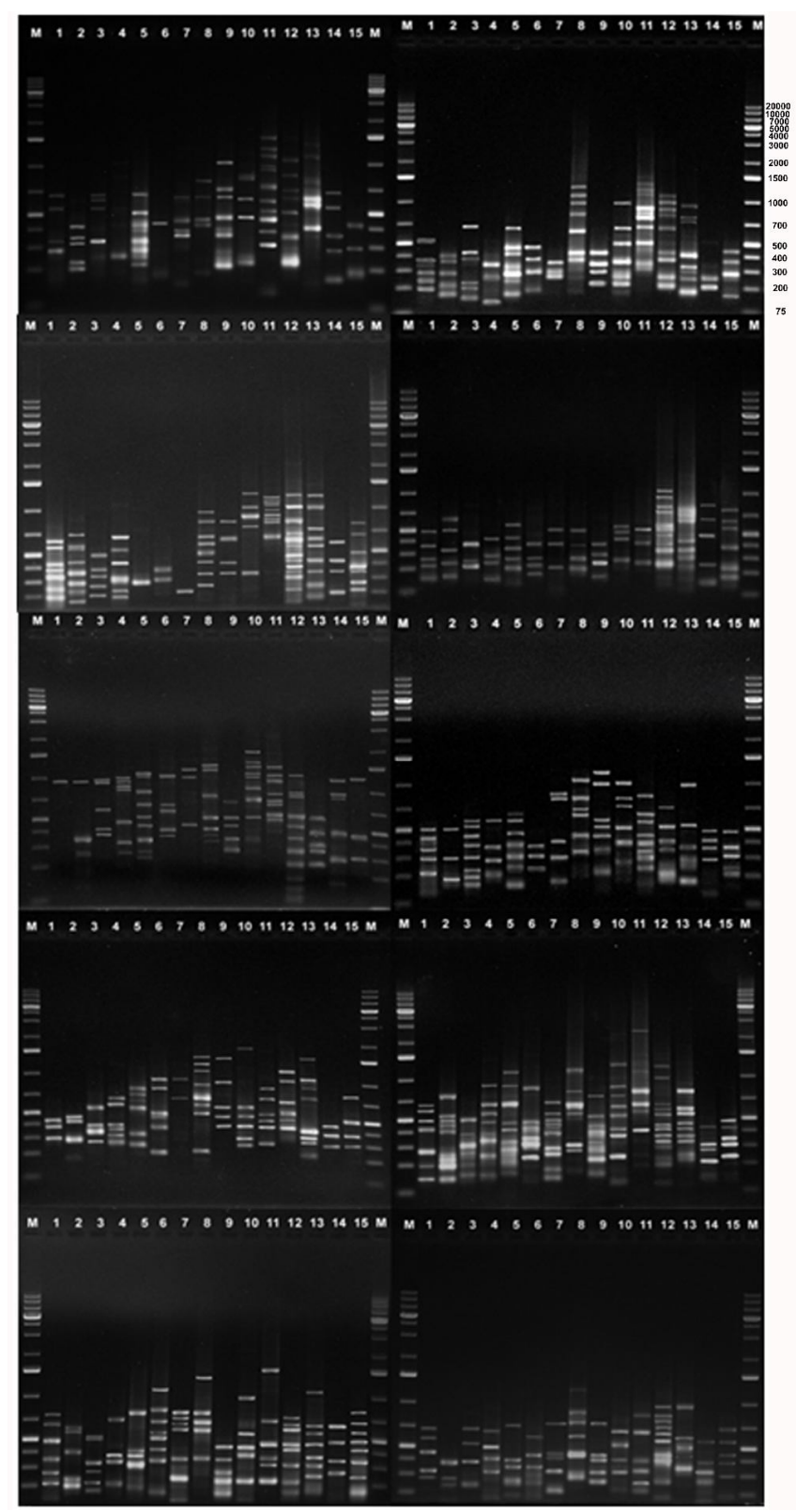

Figure 2. Electrophoresis Patterns of ISSR products amplified with primers UBC827, 812, 810, $847,857,808,855,834,840$ and 856 for Ascomycota taxa 


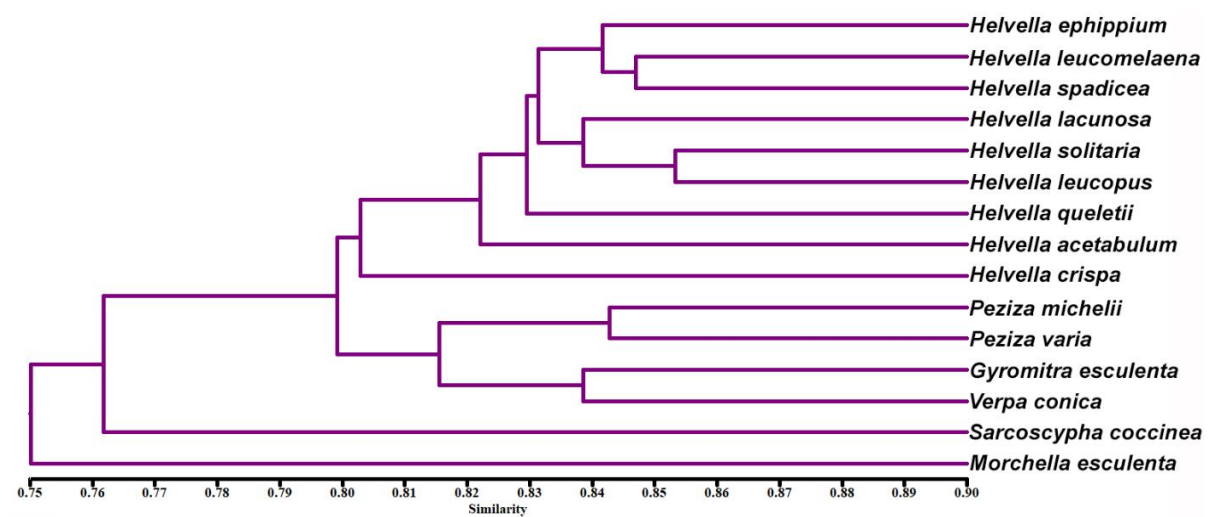

Figure 3. The dendrogram showing the genetic relationships among Ascomycota taxa based on ISSR data

\section{Morphological results}

The nMDS plots revealed the morphological differences among the studied taxa and helped to make prominent separations among them (Fig. 4). The phenogram pointed out very important characters which were very functional in classifying the fungi at different taxonomical levels (for instance, levels of species, genera, or higher). According to the phenogram (Fig. 5), it could be said that the characters belonging to the cap and the stalk are important at the primary level; hence, the taxa were divided in the main 2 groups according to these characters. Second, it was seen that the fungal species were divided into 2 subgroups according to whether the cap surface was smooth or not, and that this separation was largely compatible with previous classifications based on morphology. Finally, it was determined that the structural ornamentations made by the cap inside or outside were important in the classification of the fungi, especially to determine the 2 different groups of taxa located in the Helvella genus as saddle or cup (Fig. 5).

\section{Discussion and conclusion}

True morels (Morchella spp.) are highly popular for their edibility and appearance, and they have been examined in many broad-scale studies at different times (Kirk et al., 2011); however, other relatives have not be researched as deeply until now. We can emphasize clearly from our results that ISSR markers and morphometric analyses are very effective tools to assess close relative fungi, particularly at the genera level.

Traditionally, Verpa and Gyromitra were found to be very close to the genus Morchella and so, they were named false morels (Kirk et al., 2008). Our examinations indicated that these taxonomical groups are very close in terms of genetic and morphological features, and clear differences can be displayed among them. According to our findings, Morchella esculenta is the farthest taxa genetically and the alveolate ascocarp was not seen in any other relatives. From these, we can say that the alveolate cap is an important character for true morels to separate it from its close relative genera. Analysis of the ribosomal DNA of many of the Pezizales showed the genus Verpa to be closely related to the genus Morchella (Bunyard et al., 1995; O'Donnell et al., 1997). The results from the ISSR analyses did not exactly reflect this information, such that $S$. coccinea was positioned exceptionally among them. 


\section{Diagnostical characters of Ascomycota species Non-metric MDS}

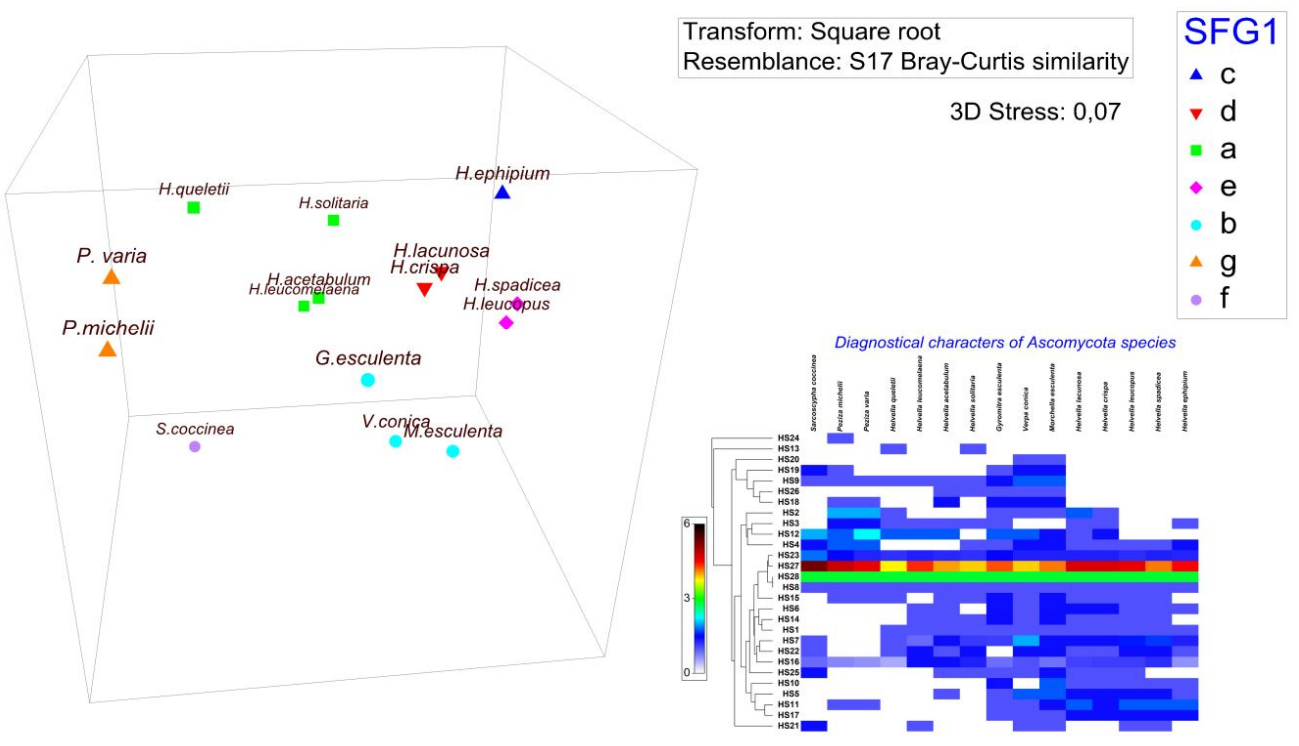

Figure 4. Two-dimensional nMDS ordination belonging to morphological characters

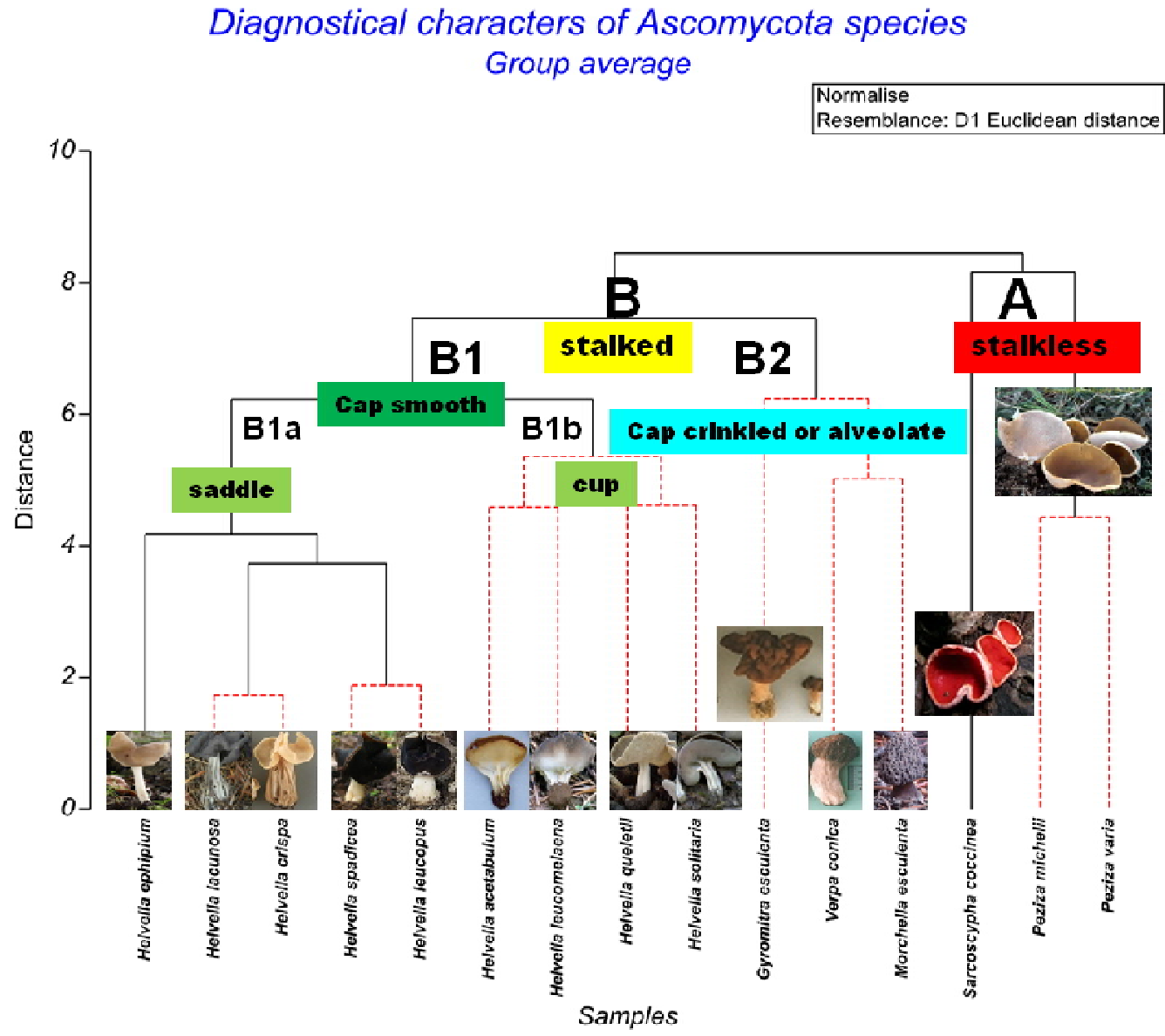

Figure 5. The phenogram showing relationships among Ascomycota taxa according to morphological characters 
The morphological data has been found largely correlated with the genetic information based on the ISSR locus analyses in except of a limited homoplasy and pseudocriptic variation. It is an interesting finding that species such as H. lacunosa and H. crispa, which are very close taxa morphologically within the genus Helvella, constituted the main body of this study, and are taken place genetically relatively remote (Fig. 3). This observed homoplasic similarity on their morphologies might be sourced from similar environmental conditions and habitats rather than genealogy. As together with this, Skrede et al. (2017) reported a pseudocryptic variation, in which 2 taxa could be recognized morphologically, only after molecular systematic data unveiled their existence. The authors suggested that the morphologically similar species pairs of $H$. corium $/ H$. macrosperma, $H$. lactea/H. pallescens, and $H$. elastica/H. panormitana, which were initially indiscernible due to the lack of discriminating morphological characters, could be resolved as genealogically exclusive using the sequence data. This was true with our 4 fungi, such as with $H$. lacunosa and H. crispa or $H$. spadicea and H. leucopus. The results indicated that these species pairs are genetically divergent and located in relatively distant related Helvella lineages according to the ISSR data. The use of molecular characters is important in cases whether the morphological characters of the taxa are identical to each other or not, or may have been reduced or absent from the taxa (Blackwell et al., 2007). The genus Helvella, which constitutes the main body of this work, is relatively taxonomically problematic and shows a series of relationships with the other genera mentioned in this paper. Although easily separated from other macrofungi by conspicuous polymorphic apothecia, it is surprisingly difficult to distinguish between Helvella species. Historically, the shape, color, and outer surface characters have been emphasized in species discrimination, while the microanatomy of the sterile and fertile structures added few characters of value in species recognition. In a previous study performed on Helvella (Weber, 1972), it was concluded that most morphological and anatomical characters exhibited a nearly continuous variation in the genus as a whole. Unlike the expressed critics, we think that the trustable and functional characters could be revealed for the genus Helvella in light of the molecular or morphological data, as illustrated via the nMDS plot of Primer7, and they could be used to explain taxonomical relationships. In conclusion, it was decided that both the stalk and cap features were quite efficient when the characters were handled comprehensively.

Acknowledgements. The authors would like to thank TÜBITAK (Project No, 111T633) and Selçuk University Scientific Research Projects (BAP, Project No. 11201012) for their financial support of this project.

\section{REFERENCES}

[1] Ariyawansa, H. A., Hyde, K. H., Jayasiri, S. C., Buyck, B., Chethana, K. W. T., Dai, D. Q., Dai, Y. C. et al. (2015): Fungal diversity notes 111-252 - taxonomic and phylogenetic contributions to fungal taxa. - Fungal Diversity 75: 27-274.

[2] Balasundaram, S. V., Engh, I. B., Skrede, I., Kauserud, H. (2015): How many DNA markers are needed to reveal cryptic fungal species. - Fungal Biology 119: 940-945.

[3] Bozkurt, M., Ertuğrul, K., Uysal, T. (2013): The determination of genetic relationships among some Vicia L. (Vetch) taxa by using ISSR markers. - Biological Diversity and Conservation 6(3): 135-139. 
[4] Bunyard, B. A., Nicholson, M. S., Royse, D. J. (1995): Phylogenetic resolution of Morchella, Verpa and Disciotis [Pezizales: Morchellaceae] based on restriction enzyme analysis of the 28S ribosomal gene. - Exp Mycol 19: 223-233.

[5] Camacho, F. J., Liston, A. (2001): Population structure and genetic diversity of Botrychium pumicola (Ophioglossaceae) based on inter-simple sequence repeats (ISSR). - Am. J. Bot. 88: 1065-1070.

[6] Clarke, K. R. (1993): Non-parametric multivariate analyses of changes in community structure. - Aust J Ecol 18: 117-143.

[7] Clarke, K. R., Warwick, R. M. (1994): Change in Marine Communities: An Approach to Statistical Analysis and Interpretation. - Natural Environment Research Council, Swindon.

[8] Cullings, K. W. (1992): Design and testing of a plant-specific PCR primer for ecological and evolutionary studies. - Molecular Ecology 1: 233-240.

[9] Fang, D. Q., Roose, M. L. (1997): Identification of closely related citrus cultivars with inter-simple sequence repeats markers. - Theor. Appl. Genet. 95: 408-417.

[10] Fuckel, L. (1870): Symbolae mycologicae. Beiträge zur Kenntnis der rheinischen Pilze [Contributions to the knowledge of mushrooms of the Rhein]. - Jahrbücher des Nassauischen Vereins für Naturkunde 23-24: 324 (in German).

[11] Holmskjold T (1799): Beata Ruris Otia Fungis Danicis. - Sumtibus Universitatis Bibliopolae Friderico Brummer, Havniae (in Latin)

[12] Jacquin, N. J. (1774): Flora Austriaca. - Vienna, Austria.

[13] Kanouse, B. C. (1948): The genus Plectania and its segregates in North America. Mycologia 40(4): 482-97. DOI: 10.2307/3755155. JSTOR 3755155.

[14] Korf, R. P., Harrington, F. A. (1990): Proposal to conserve a type for Sarcoscypha (Fries) Boudier, S. coccinea (Jacq.) Lambotte (Fungi). - Taxon. 39(2): 342-3. DOI: 10.2307/1223069. JSTOR 1223069.

[15] Kuo, M. (2014): Contributors. - http://www.mushroomexpert.com/contributors.html.

[16] Kirk, P. M., Cannon, P. F., Minter, D. W., Stalpers, J. A. (2008): Dictionary of the Fungi (10th Ed.). - CABI, Wallingford, UK.

[17] Lambotte, J. B. E. (1889): Sarcoscypha coccinea (Scop.). - MycoBank, International Mycological Association (retrieved 2010-08-21).

[18] Landeros, F., Iturriaga, T., Rodriguez, A., Vargas-Amadoc, G., Guzmán-Dávalos, L. (2015): Advances in the phylogeny of Helvella (Fungi: Ascomycota), inferred from nuclear ribosomal LSU sequences and morphological data. - Revista Mexicana de Boversidad 86: 856-871.

[19] Landvik, S., Kristiansen, R., Schumacher, T. (1999): Pindara: a miniature Helvella. Mycologia 91: 278-285.

[20] Le Gal, M. (1953): Les Discomycètes de Madagascar [The Discomycetes of Madagascar]. Prodrome à Flore Mycologique de Madagascar et Dépendanes. - Muséum National d'Histoire Naturelle, Paris 4: 1-465 (in French).

[21] Nannfeldt, J. A. (1949): Contributions to the microflora of Sweden. 7. A new winter Discomycete, Urnula hiemalis Nannf. n. sp., and a short account of the Swedish species of Sarcoscyphaceae. - Svensk Botanisk Tidskrift. 43: 468-84.

[22] Nazrul, M. I., Bian, Y. B. (2010): Efficiency of RAPD and ISSR markers in differentiation of homo- and heterokaryotic protoclones of Agaricus bisporus. - J. Microbiol. Biotechnol. 20(4): 683-692.

[23] Nguyen, N. H., Landeros, F., Garibay-Orijel, R., Hansen, K., Vellinga, E. C. (2013): The Helvella lacunosa species complex in western North America: cryptic species, misapplied names and parasites. - Mycologia 105(5): 1275-1286.

[24] O’Donnell, K., Cigelnik, E., Weber, N. S., Trappe, J. M. (1997): Phylogenetic relationships among ascomycetous truffles and the true and false morels inferred from $18 \mathrm{~S}$ and 28S ribosomal DNA sequence analysis. - Mycologia 89(1): 48-65. DOI: 10.2307/3761172. JSTOR 3761172. 
[25] Prevost, A., Wilkinson, M. J. (1999): A new system of comparing PCR primers applied to ISSR fingerprinting of potato cultivars. - Theor. Appl. Genet. 98: 107-112.

[26] Rohlf, F. J. (1998): NTSYSpc Numerical Taxonomy and Multivariate Analysis System User Guide. - Exeter Software, New York, 0-925031-28-3.

[27] Scopoli, G. A. (1772): Flora Carniolica. 2nd Ed.. - Sumptibus J. T. Trattner, Vienna (in Latin).

[28] Seaver, F. J. (1928): The North American Cup-Fungi (Operculates). - Self Published, New York, pp. 191-2.

[29] Sesli, E., Denchev, C. M. (2014): Checklists of the Myxomycetes, Larger Ascomycetes, and Larger Basidiomycetes in Turkey. 6th Ed. - Mycotaxon Checklists Online. http://www.mycotaxon.com/resources/checklists/sesli-v106-checklist.pdf.

[30] Skrede, I., Carlsen, T., Schumacher, T. (2017): A synopsis of the saddle fungi (Helvella: Ascomycota) in Europe-species delimitation, taxonomy and typification. - Persoonia 39: 201-253.

[31] Soltis, D. E., Collõer, T. G., Edgerton, M. L. (1991): The Heuchera group (Saxifragaceae): Evidence for chloroplast transfer and paraphyly. - Amer. J. Bot.78: 1091-1112.

[32] Song, Z. P., Guan, Y., Rong, J., Xu, X., Lu, B. R. (2006): Inter-simple sequence repeat (ISSR) variation in populations of the cutgrass Leersia hexandra. - Aquat. Bot. 84: 359362.

[33] Stefani, O. P. F., Sokolski, S., Wurtz, T., Piche, Y., Hamelin, R., Fortin, A., Berube, J. A. (2010): Morchella tomentosa: a unique belowground structure and a new clade of morels. - Mycologia 102: 1082-1088.

[34] Tang, L. H., Xiao, Y., Bian, Y. B. (2005): The orthogonal optimization of ISSR-PCR amplification system in Auricularia auricula. - J. Fungal Res. 3: 15-18.

[35] Tsumura, Y., Ohba, K., Strauss, S. H. (1996): Diversity and inheritance of inter-simple sequence repeat polymorphisms in Douglas-fir (Pseudotsuga menziesii) and sugi (Cryptomeria japonica). - Theor. Appl. Genet. 92: 40-45.

[36] Uysal, T., Özel, E., Bozkurt, M., Ertuğrul, K. (2012a): Genetic diversity in threatened populations of the endemic species Centaurea lycaonica Boiss. \& Heldr. (Asteraceae). Research Journal of Biology 2(3): 110-116.

[37] Uysal, T., Özel, E., Ertuğrul, K., Bozkurt, M. (2012b): Determination of genetic relationship among Cheirolepis (Centaurea/Asteraceae) section and its relatives in Turkey. - Research Journal of Biology 2(3): 104-109.

[38] Weber, N. S. (1972): The genus Helvella in Michigan. - The Michigan Botanist 11: 147201.

[39] Wolfe, A. D., Liston, A. (1998): Contributions of PCR-Based Methods to Plant Systematics and Evolutionary Biology. - In: Soltis, D. E., Soltis, P. S., Doyle, J. J. (eds.) Molecular Systematics of Plants II: DNA Sequencing. Kluwer, New York, pp. 43-86.

[40] Yoon, C. S., Gessner, R. V., Romano, M. A. (1990): Population genetics and systematics of the Morchella esculenta complex. - Mycologia 82: 227-235.

[41] Zhao, Q., Zhang, X., Li, S., Chai, H., Bahkali, A. H., Hyde, K. D. (2017): New species and records of saddle fungi (Helvella, Helvellaceae) from Jiuzhaigou Natural Reserve, China. - Mycoscience 57: 422-430.

[42] Zietkiewicz, E., Rafalski. A., Labuda, D. (1994): Genome fingerprinting by simple sequence repeat (SSR)-anchored polymerase chain reaction amplification. - Genomics 20: $176-183$. 